\title{
Diagnostic of peripheral longitudinal grinding by using acoustic emission signal
}

\author{
Zylka, L. ${ }^{a}{ }^{*}$, Burek, J. ${ }^{a}$, Mazur, D. ${ }^{b}$ \\ ${ }^{a}$ Department of Manufacturing Techniques and Automation, Rzeszow University of Technology, Poland \\ ${ }^{b}$ Department of Electrical and Computer Engineering Fundamentals, Rzeszow University of Technology, Poland
}

\section{A B S T R A C T}

Grinding burn is one of the well-known problems in grinding processes. The phenomenon of burns causes permanent damage to the ground surface. Therefore, there is a need of monitoring the grinding processes in order to prevent surface damage of a workpiece. This paper presents a method of diagnosing grinding wheel wear with the use of acoustic emission signal generated during grinding. The method aims to detect the occurrence of burn in the surface layer of ground workpieces, and, thus, to replace costly and troublesome surface layer control methods performed after grinding. Experimental research of the grinding process together with the control of surface layer condition was conducted by means of the nital etching method. A band analysis of acoustic emission signal was completed and the influence of the grinding burns phenomenon on the signal amplitude in the range of low frequencies was presented. A boundary value of the $A E$ describing the appearance of grinding burns was determined. Moreover, $R M S$ value of acoustic emission signal was analysed, and the influence of grinding wheel wear on the signal variations was determined. A new parameter was proposed in order to determine the end of grinding wheel life-time. A boundary value of this $A E$ parameter, which indicates the excessive wear of grinding wheel was determined.
\end{abstract}

\begin{tabular}{l} 
A R T I C L E I N F O \\
\hline Keywords: \\
Grinding \\
Grinding burns \\
Grinding wheel \\
Diagnostic \\
Acoustic emission \\
*Corresponding author: \\
zylka@prz.edu.pl \\
(Zylka, L.) \\
Article history: \\
Received 5 May 2017 \\
Revised 6 July 2017 \\
Accepted 10 July 2017
\end{tabular}

Grinding burns

Grinding wheel

Diagnostic

Acoustic emission

${ }^{*}$ Corresponding author:

zylka@prz.edu.pl

(Zylka, L.)

Accepted 10 July 2017

\section{References}

[1] Nadolny, K. (2013). A review on single-pass grinding processes, Journal of Central South University, Vol. 20, No. 6, 1502-1509, doi: 10.1007/s11771-013-1641-5.

[2] Demir, H., Gullu, A., Ciftci, I., Seker, U. (2010). An investigation into the influences of grain size and grinding parameters on surface roughness and grinding forces when grinding, Strojniški vestnik - Journal of Mechanical Engineering, Vol. 56, No. 7-8, 447-454.

[3] Klocke, F., König, W. (2005). Fertigungsverfahren - Schleifen, Honen, Läppen, $4^{\text {th }}$ edition, Springer, Berlin, Heidelberg, Germany, doi: 10.1007/3-540-27699-8.

[4] Malkin, S., Guo, C. (2008). Grinding technology: Theory and applications of machining with abrasives, Industrial Press, New York, USA.

[5] De Aguiar, P.R., Bianchi, E.C., Serni, P.J.A., Lanconi, P.N. (2002). Control of thermal damage in grinding by digital signal processing of raw acoustic emission, In: Seventh International Conference on Control, Automation, Robotics and Vision (ICARCV'02), Singapore, 1392-1397, doi: 10.1109/ICARCV.2002.1234976.

[6] Dotto, F.R.L., De Aguiar, P.R., Bianchi, E.C., Flauzino, R.A., Castelhano, G.O., Pansanato, L. (2003). Automatic detection of thermal damage in grinding process by artificial neural network, Rem: Revista Escola de Minas, Vol. 56, No. 4, 295-300, doi: 10.1590/S0370-44672003000400013.

[7] Sinha, M.K., Setti, D., Ghosh, S., Rao, P.V. (2016). An investigation on surface burn during grinding of Inconel 718, Journal of Manufacturing Processes, Vol. 21, 124-133, doi: 10.1016/i.jmapro.2015.12.004. 
[8] Azarhoushang, B., Daneshi, A., Lee, D.H. (2017). Evaluation of thermal damages and residual stresses in dry grinding by structured wheels, Journal of Cleaner Production, Vol. 142, Part 4, 1922-1930, doi: 10.1016/i.jclepro. 2016. 11.091.

[9] Sutowski, P., Nadolny, K., Kaplonek, W. (2012). Monitoring of cylindrical grinding processes by use of a noncontact AE system, International Journal of Precision Engineering and Manufacturing, Vol. 13, No. 10, 1737-1743, doi: $10.1007 / \mathrm{s} 12541-012-0228-7$.

[10] Kruszyński, B.W., Lajmert, P. (2005). An intelligent supervision system for cylindrical traverse grinding, CIRP Annals - Manufacturing Technology, Vol. 54, No. 1, 305-308, doi: 10.1016/S0007-8506(07)60109-7.

[11] Mičietová, A., Neslušan, M., Čep, R., Ochodek, V., Mičieta, B., Pagáč, M. (2017). Detection of grinding burn through the high and low frequency Barkhausen noise, Tehnički vjesnik - Technical Gazette, Vol. 24, No. 1, 71-77, doi:10.17559/TV-20140203083223.

[12] Neslušan, M., Č́ížek, J., Kolařík, K., Minárik, P., Čilliková, M., Melikhova, O. (2017). Monitoring of grinding burn via Barkhausen noise emission in case-hardened steel in large-bearing production, Journal of Materials Processing Technology, Vol. 240, 104-117, doi: 10.1016/i.jmatprotec.2016.09.015.

[13] Kruszyński, B.W., Lajmert, P. (2006). An intelligent system for online optimization of the cylindrical traverse grinding operation, Proceedings of the Institution of Mechanical Engineers, Part B: Journal of Engineering Manufacture, Vol. 220, No. 3, 355-363, doi: 10.1243/095440506X77607.

[14] Sutowski, P., Plichta, J. (2006). An investigation of the grinding wheel wear with the use of root-mean-square value of acoustic emission, Archives of Civil and Mechanical Engineering, Vol. 6, No. 1, 87-98, doi: 10.1016/S16449665(12)60078-8.

[15] Aguiar, P.R., Serni, P.J.A., Dotto, F.R.L., Bianchi, E.C. (2006). In-process grinding monitoring though acoustic emission, Journal of the Brazilian Society of Mechanical Science and Engineering, Vol. 28, No. 1, 118-124, doi: 10.1590/S1678-58782006000100014.

[16] Lv, C., Li, H. (2010). Acoustic emission signal processing of grinding monitor, In: 2010 3rd International Congress on Image and Signal Processing, Yantai, China, 3836-3838, doi: 10.1109/CISP.2010.5646807.

[17] Kwak, J.-S., Ha, M.-K. (2004). Neural network approach for diagnosis of grinding operation by acoustic emission and power signals, Journal of Materials Processing Technology, Vol. 147, No. 1, 65-71, doi: 10.1016/j.jmatprotec. 2003.11.016.

[18] Wang, Z., Willett, P., DeAguiar, P.R., Webster, J. (2001). Neural network detection of grinding burn from acoustic emission, International Journal of Machine Tools and Manufacture, Vol. 41, No. 2, 283-309, doi: 10.1016/S08906955(00)00057-2.

[19] Liu, Q., Chen, X., Gindy, N. (2005). Fuzzy pattern recognition of AE signals for grinding burn, International Journal of Machine Tools and Manufacture, Vol. 45, No. 7-8, 811-818, doi: 10.1016/j.ijmachtools.2004.11.002.

[20] Liu, Q., Chen, X., Gindy, N. (2006). Investigation of acoustic emission signals under a simulative environment of grinding burn, International Journal of Machine Tools and Manufacture, Vol. 46, No. 3-4, 284-292, doi: 10.1016/ j.ijmachtools.2005.05.017.

[21] Kwak, J.-S., Song, J.-B. (2001). Trouble diagnosis of the grinding process by using acoustic emission signals, International Journal of Machine Tools and Manufacture, Vol. 41, No. 6, 899-913, doi: 10.1016/S0890-6955(00) $\underline{00082-1}$.

[22] Saravanapriyan, S.N.A., Vijayaraghavan, L., Krishnamurthy, R. (2001). On-line detection of grinding burn by integrated sensing, In: SIcon'01 Sensors for Industry Conference, Proceedings of the First ISA/IEEE Conference, Illinois, USA, 89-94, doi: 10.1109/SFICON.2001.968505.

[23] Griffin, J.M., Chen, X. (2009). Multiple classification of the acoustic emission signals extracted during burn and chatter anomalies using genetic programming, International Journal of Advanced Manufacturing Technology, Vol. 45, No. 11-12, 1152-1168, doi: 10.1007/s00170-009-2026-7.

[24] Kwak, J-S., Ha, M.-K. (2004). Neural network approach for diagnosis of grinding operation by acoustic emission and power signals, Journal of Materials Processing Technology, Vol. 147, No. 1, 65-71, doi: 10.1016/i.jmatprotec. 2003.11.016.

[25] Yang, Z., Yu, Z., Xie, C., Huang, Y. (2014). Application of Hilbert-Huang transform to acoustic emission signal for burn feature extraction in surface grinding process, Measurement, Vol. 47, 14-21, doi: 10.1016/i.measurement. 2013.08.036.

[26] Liao, T.W., Tang, F., Qu, J., Blau, P.J. (2008). Grinding wheel condition monitoring with boosted minimum distance classifiers, Mechanical Systems and Signal Processing, Vol. 22, No. 1, 217-232, doi: 10.1016/i.ymssp.2007.06.005. 


\title{
Diagnostika stranskega vzdolžnega brušenja z uporabo emisije akustičnega signala
}

\author{
Zylka, L. ${ }^{a,}{ }^{,}$, Burek, J. ${ }^{a}$, Mazur, D. ${ }^{b}$ \\ ${ }^{a}$ Department of Manufacturing Techniques and Automation, Rzeszow University of Technology, Poland \\ ${ }^{b}$ Department of Electrical and Computer Engineering Fundamentals, Rzeszow University of Technology, Poland
}

\section{POVZETEK}

Ožganine so ena izmed dobro znanih težav pri brušenju in predstavljajo trajno poškodbo na obdelani površini. Da se prepreči površinske poškodbe obdelovanca je potreben nadzor procesa brušenja. Prispevek predlaga metodo za zaznavo obrabe brusilnega koluta na osnovi emisije akustičnega signala. Namen metode je zaznati nastanek ožganin v površinski plasti obdelovancev med brušenjem in tako nadomestiti drage in težavne kontrolne metode po brušenju. Eksperimentalne raziskave postopka brušenja skupaj s kontrolo stanja površinske plasti so bile izvedene z metodo nitalnega jedkanja. $\mathrm{Na}$ osnovi analize signala akustičnih emisij je predstavljen vpliv motečih ožganin na amplitudo signala v območju nizkih frekvenc. Določena je bila mejna vrednost akustičnih emisij (AE) pri kateri se pojavijo ožganine. Določen je bil tudi vpliv obrabe brusilnega koluta na spremembo signala akustičnih emisij. Vpeljali smo nov parameter za določitev konca življenjske dobe brusilnega koluta. Določena je bila tudi mejna vrednost parametra akustičnih emisij, ki predstavlja prekomerno obrabo brusilnega koluta.

\section{PODATKI O ČLANKU}

Ključne besede:

Brušenje

Ožganine pri brušenju

Brusilni kolut

Diagnostika

Akustične emisije

*Kontaktna oseba: zylka@prz.edu.pl

(Zylka, L.)

Zgodovina članka:

Prejet 5. maja 2017

Popravljen 6. julija 2017

Sprejet 10. julija 2017 